\title{
Effect of processing on nutritional and antinutritional composition of bathua (Chenopodium album) leaves
}

\begin{abstract}
Gaganpreet Kaur*
Junior Dietician, Hero DMC Heart Institute, Ludhiana (Punjab), India

Navjot Kaur

Department of Food and Nutrition, Punjab Agricultural University, Ludhiana-141004

(Punjab), India

*Corresponding author. E-mail: diljotbasra19@yahoo.in

Abstract

Bathua (Chenopodium album) leaves were undertaken for different processing techniques and analyzed for their nutritional and anti-nutritional composition. Effect of processing on nutrient retention was assessed to attain the best processed form of leaves with maximum amount of nutrients. It was observed that the Cabinet dried processing improved the protein, fibre and ash content of leaves by $29.30,5.74$ and 16.42 percent respectively. Shade and cabinet dried technique improved the vitamin $\mathrm{C}$ and $\beta$-carotene by 34 and 14323 percent respectively. Maximum retention of calcium and iron was found in cabinet dried technique. It also improved magnesium by 254.50 percent. Amino acid retention was found maximum in cabinet dried technique. Cabinet dried technique improved In vitro protein digestibility by 27.75 percent with a decrease of 116.15 and 85.30 percent in phytates and oxalates respectively. Maximum retention of nutrients was observed in cabinet dried technique.
\end{abstract}

Keywords: Anti-nutrients, Bathua leaves, Nutritional composition, Nutrients, Processing

\section{Article Info}

DOI:10.31018/jans.v10i4.1856

Received: August 9, 2018

Revised: September 27, 2018

Accepted: October 15, 2018

\section{How to Cite}

Kaur, G. and Kaur, N. (2018). Effect of processing on nutritional and antinutritional composition of bathua (Chenopodium album) leaves. Journal of Applied and Natural Science, 10(4): $1149-1155$

\section{INTRODUCTION}

Chenopodium album belongs to the family Chenopodiaceae, a fast-growing weedy annual plantand is largely cultivated in agricultural land and gardens and it is distributed all over South East Asia. It is mostly found around the areas of Sikkim, Mumbai, Kashmir and throughout Pakistan. It is commonly called 'white goose foot', whereas in Pakistan's local language, it is called 'bathua'. It can be used in traditional recipes and consumed as a food product. The leaves of this plant are often used in cooking as they are extremely nutritious and also play a vital role in therapeutic nutrition (Ahmad et al., 2012).

Due to its health promoting benefits, $C$. album has been considered as an important nutritional and medicinal plant in Ayurveda. It helps in diseases of blood, heart, spleen, eye and biliousness conditions, cough, abdominal pain, pulmonary obstruction and in nervous affections. Pharmacological studies on the plant reveals the proven activity of its as hypoglycemic, antibacterial, spasmolytic, antipruritic, anti-inflammatory, hepatoprotective, antioxidant and anticancer properties (Sikarwaret al., 2013).

The leaves of bathua contain various nutrients such as moisture $(89.65 \%)$, protein $(3.7 \%)$, fat $(0.4 \%)$, other carbohydrates $(2.9 \%)$. It is good source of thiamine $(0.01 \mathrm{mg})$, niacin $(0.6 \mathrm{mg})$, vita- $\min C(35 \mathrm{mg}), \beta$-carotene $(1.470 \mu \mathrm{g})$ per 100 gram along with traces of iodine, fluorine, and vitamin K. It is also a good source of calcium (15 $\mathrm{mg} / 100 \mathrm{~g}$ ) and phosphorus (8 mg $/ 100 \mathrm{~g}$ ) which helps in maintaining strong bones and has also role in cell signaling, blood clotting, muscle contraction and nerve function. Iron $(4.2 \mathrm{mg} / 100 \mathrm{~g})$ in the leave soften helps to cure mild anemic conditions, especially in children. The leaves also contains essential amino acids like leucine, isoleucine, lysine, methionine, phenylalanine, threonine, valine and tryptophan (Pandey and Pathak 2009). The phytochemical content of bathua was analyzed and found to be very promising. On dry weight basis, the values of saponins $(0.46 \mathrm{~g} / 100 \mathrm{~g})$ and crude alkaloids $(9.7 \mathrm{~g} / 100 \mathrm{~g})$ were determined. Alkaloids acts as antispasmodic and analgesic agents while saponins help in promoting the immune system, in decreasing cholesterol levels in the blood. Various studies have revealed that phenolic compounds favours beneficial health effects. Phenolics scavenge the free radicals that provide the plants with defense mechanisms in order to prevent from harmful health effects by microorganisms and insects. Flavonoids show a wide range of biological activities such as inhibition of cell-proliferation, induction of apoptosis (cell death) and other antibacterial and antioxidant effects (Pandey and Gupta, 2014). It can be saidlike leaves can be used to combat calcium, iron and 
vitamin A deficiency as they are good source of micronutrients.

Since, it is uncommon, underutilized crop (Hernandez and Leon 1994) which is not used regularly in Indian homes because of the unawareness of people. In India the leaves are used either in raw or processed forms. Processing by different techniques (sun, shade, solar, cabinet drying) reduce the moisture content, enhance its shelf life, improve its quality, preserve and enhance its nutritional quality, makesit available throughout the year even in off season thus supplying the important nutrients in concentrated form (Gupta et al. 2011). In India, no study has been conducted which evaluated the effect of different processing techniques on the nutritional quality of leaves. So keeping all the points in view, a study has been carried out to evaluate the effect of different processing techniques on the nutritional and anti-nutritional quality of the leaves and to findout the best method to use leaves with maximum nutrients for its better utilization. The study will be helpful in popularizing the leaves and their nutritional benefits and prove a good choice for combating malnutrition in developing countries like India.

\section{MATERIALS AND METHODS}

\section{Procurement and processing of leaves}

Procurement of sample: Fresh (Chenopodium album) have been procured from the Department of Agronomy, Punjab Agricultural University Ludhiana. The fresh leaves were thoroughly washed, dried and used for the study.

\section{Dehydration of leaves}

Sorting and washing of leaves: Bathua leaves sorted with healthy leaves were washed thoroughly by dipping in water for one minute. The procedure was repeated till the leaves were devoid of dirt and soil.

Blanching and dehydration of fresh leaves: The leaves were blanched for 1-2 minutes and dried by various techniques such as sun drying, shade drying, solar drying and in cabinet drier $\left(60^{\circ} \mathrm{C}\right.$ for $10-12$ hours) till moisture content reaches to $6-7 \%$.

The dehydrated leaves were powdered and packed in low density polythene bags and stored in air tight containers until used for chemical analysis. Effect of processing leaves has been studied by comparing chemical composition of fresh and processed leaves.

\section{Nutritional analysis}

Proximate composition: Proximate composition viz. moisture, crude protein, crude fat, crude fibre, ash was analyzed by standard methods (AOAC,2000). The moisture content of raw and processed leaves were determined by drying the samples in cabinet drier at $105^{\circ} \mathrm{C}$. Protein $(\mathrm{N} \times$ 5.30) (Swaminathan, 1974) was calculatedby de- termining total nitrogen employing Micro Kjeldahl method (Kel Plus Classic, Pelican Equipment Inc., India). Crude fat was extracted with petroleum ether, using Socs Plus and for fibre, acid alkali washing was given in Fibra Plus Apparatus (Pelican Equipment Inc., India). The available carbohydrates were calculated by adding the value of moisture, crude protein, crude fat, fibre and ash which was then subtracted from 100.. Gross energy was computed with the help of formula mentioned below

Gross Energy $=($ Crude protein $\times 4)+($ Crude fat $\times$ 9) + (Carbohydrate $\times 4)$

Vitamin content: The individual carotenoids were determined spectrophotometrically and separated on a column of calcium hydroxide of alumina (Rangana, 1995) and vitamin C was estimated through reduction of dye (AOVC,1996).

Total minerals: For minerals, the samples were wet digested in hot plate using nitric acid and perchloric acid mixture in 5:1 ratio (v/v) and used for the determination of total amount of calcium, iron, magnesium and zinc by atomic absorption spectrophotometry (AOAC, 2000)

Amino acids estimation: Extraction of sulphur amino acids was done by hydrolysing the samples in autoclave for $6 \mathrm{~h}$ at $15 \mathrm{lb}$ pressure. After filtration, hydrolyzed samples were used for the determination of methionine (Horn, Jones and Blum, 1946), Lysine was assessed by method of Booth (1971) and estimation of tryptophan was done by Concon (1975).

In vitro protein digestibility: In vitroprotein digestibility was assessed by Akeson and Stachman (1964) method. The samples were digested with pepsin solution followed by pancreatin solution and incubated at $37^{\circ} \mathrm{C}$ for $24 \mathrm{~h}$. The residue was analysed for nitrogen content by MacroKjeldahl method. The digestibility co-efficient of the protein was determined by subtracting the residual protein from the initial protein on the basis of $100 \mathrm{~g}$ of the sample.

Antinutritional factors: Oxalic acid was estimated by titring oxalates containing sulphuric acid against potassium permanganate as given by $\mathrm{Ab}$ eza et al (1968) and extraction of phytin phosphorus was determined by employing hydrochloric acid and keeping the solution for $3 \mathrm{~h}$. Amount of phytin phosphorus was calculated by using 2, 2 bipyridine solution on spectrophotometer (Haug and Lantzsch, 1983).

Statistical analysis: The values were taken in triplicate and the results are given in mean \pm standard deviation. Data were subjected to statistical analysis using Statistical Package for Social Sciences (SPSS) version 16.0. Tukey test was used to compare the significant differences in mean values obtained after processing of bathua leaves. Level of significance was expressed at $p$ $<0.05$. 


\section{RESULTS AND DISCUSSION}

Proximate composition: The proximate composition of fresh and dehydrated bathua leaves has been in Table 1.

The protein content of fresh bathua leaves was found to be 3.20 percent while with dehydration this value was increased. Maximum protein was found in cabinet dried leaves i.e.31.20percent. Maximum decrease in protein content was analyzed with shade $(26.50 \%)$, followed by solar $(28.55 \%)$ and sun dried $(29.30 \%)$. Significant difference was found among all treatments including fresh leaves $(p \leq 0.05)$. The value of protein content of fresh and dehydrated leaves was almost agreement with Singh et al. (2007) who reported 3.7 and 32.95 percent protein respectively.

Sun dried leaves were found to have maximum fat content of 1.62 percent whereas fresh leaves have 0.55 percent. Minimum fat content was found in shade dried leaves. The value of fat content of fresh and dehydrated was almost similar with the results of Singh et al. (2007) who report- ed 0.63 percent and 1.16 percent fat respectively. Fibre content of fresh leaves was recorded lower $(1.05 \%)$ than that of reported value $(11 \%)$ by Vishwakarma and Dubey (2011). There was significantly $(p \leq 0.05)$ increase in the fibre content of dehydrated leaves and maximum content of fibre was found in cabinet dried leaves $(6.20 \%)$ followed by sun $(5.74 \%)$, solar $(5.05 \%)$ and shade $(4.83 \%)$ dried leaves.

On dehydration, there was significant $(p \leq 0.05)$ increase in ash content, however maximum increment was found in cabinet dried leaves i.e.17.45 percent as compared to fresh leaves i.e. 2.06 percent. The values agreewith the findings of Kowsalyaand Vidhya (2004) who reported $2.1 \mathrm{~g} / 100 \mathrm{~g}$ in fresh and $12 \mathrm{~g} / 100 \mathrm{~g}$ (Sun dried), $14 \mathrm{~g} / 100 \mathrm{~g}$ (Shade dried) and $15 \mathrm{~g} / 100 \mathrm{~g}$ (Cabinet dried)Arai kerrai leaves.

Carbohydrate content of fresh leaves was found to be $93.15 \mathrm{~g}$ while with sun, shade, solar and cabinet dried leaves, these values were estimated as $46.94,54.43,49.19,44.26 \mathrm{~g}$ respectively. The re-

Table 1. Effect of processing on the proximate composition of fresh and dried leaves of bathua by different techniques (DM basis).

\begin{tabular}{llllllll}
\hline Treatment & $\begin{array}{l}\text { Moisture } \\
(\%)\end{array}$ & $\begin{array}{l}\text { Crude } \\
\text { protein(\%) }\end{array}$ & $\begin{array}{l}\text { Crude } \\
\text { fat(\%) }\end{array}$ & $\begin{array}{l}\text { Crude } \\
\text { fibre(\%) }\end{array}$ & $\begin{array}{l}\text { Total } \\
\text { ash(\%) }\end{array}$ & CHO* $^{*}(\mathbf{g})$ & $\begin{array}{l}\text { Energy } \\
\text { (Kcal) }\end{array}$ \\
\hline Fresh leaves & $86.7 \pm 0.71$ & $3.20 \pm 0.14$ & $0.55 \pm 0.7$ & $1.05 \pm 0.7$ & $2.06 \pm 0.04$ & $93.15 \pm 0.18$ & $390.33 \pm 0.78$ \\
Dehydrated leaves & & & & & & & \\
Sun dried & $9.35 \pm 0.35$ & $29.30 \pm 0.14$ & $1.62 \pm 0.05$ & $5.74 \pm 0.09$ & $16.42 \pm 0.23$ & $46.94 \pm 0.05$ & $319.48 \pm 0.32$ \\
Solar dried & $8.77 \pm 0.18$ & $28.55 \pm 0.21$ & $1.40 \pm 0.18$ & $5.05 \pm 0.11$ & $15.83 \pm 0.29$ & $49.19 \pm 0.22$ & $324.61 \pm 0.05$ \\
Shade dried & $10.3 \pm 0.76$ & $26.50 \pm 0.57$ & $0.73 \pm 0.07$ & $4.83 \pm 0.09$ & $13.52 \pm 0.06$ & $54.43 \pm 0.49$ & $329.55 \pm 0.08$ \\
Cabinet dried & $8.19 \pm 0.10$ & $31.20 \pm 0.14$ & $0.90 \pm 0.01$ & $6.20 \pm 0.11$ & $17.45 \pm 0.04$ & $44.26 \pm 0.19$ & $309.55 \pm 0.20$ \\
f value & $8.657^{*}$ & $74.613^{*}$ & $35.287^{*}$ & $80.602^{*}$ & $154.234^{*}$ & $458.536^{*}$ & $3925.631^{*}$ \\
\hline
\end{tabular}

Values are expressed as Mean \pm SE, * Significant at $5 \%$ level, Samples were taken in triplicate, ${ }^{*}$ Carbohydrate $=100 \_(\text {Protein }+ \text { Fat }+ \text { Fibre }+ \text { Ash }),{ }^{* *}$ Energy $=($ Protein $\times 4)+($ Carbohydrate $\times 4)+($ Fat $\times 9)$.

Table 2. Effect of processing on vitamin content of fresh and dried leaves of bathua by different techniques (fresh weight basis).

\begin{tabular}{lll}
\hline Treatment & Vitamin C $(\mathbf{m g} / \mathbf{1 0 0 g})$ & b-carotene $(\boldsymbol{\mu g} / \mathbf{1 0 0 g})$ \\
\hline Fresh leaves & $37.00 \pm 1.41$ & $1700.00 \pm 15.56$ \\
Dehydrated leaves & & \\
Sun dried & $26.00 \pm 2.83$ & $12892.50 \pm 2.12$ \\
Solar dried & $32.00 \pm 1.41$ & $11604.50 \pm 9.19$ \\
Shade dried & $34.00 \pm 2.83$ & $13990.00 \pm 4.24$ \\
Cabinet dried & $21.00 \pm 1.41$ & $14323.50 \pm 3.54$ \\
f value & $45.467^{*}$ & $160.54^{*}$ \\
\hline
\end{tabular}

Values are expressed as Mean \pm SE; * Significant at $5 \%$ level, Samples were taken in triplicate.

Table 3. Effect of processing on the mineral content of fresh and dried leaves of bathua different techniques (DM basis).

\begin{tabular}{lllll}
\hline Treatment & Calcium $(\mathbf{m g} / \mathbf{1 0 0})$ & Iron $(\mathbf{m g} / \mathbf{1 0 0 g})$ & Magnesium $(\mathbf{m g} / \mathbf{1 0 0 g})$ & Zinc $(\mathbf{m g} / \mathbf{1 0 0})$ \\
\hline Fresh leaves & $142.50 \pm 2.12$ & $4.15 \pm 0.35$ & $53.50 \pm 2.12$ & $0.50 \pm 0.14$ \\
Dehydrated leaves & & & & \\
Sun dried & $654.50 \pm 3.54$ & $22.28 \pm 0.01$ & $191.50 \pm 0.71$ & $1.61 \pm 0.04$ \\
Solar dried & $549.00 \pm 2.83$ & $21.67 \pm 0.02$ & $157.00 \pm 1.41$ & $1.49 \pm 0.03$ \\
Shade dried & $691.00 \pm 2.83$ & $24.45 \pm 0.05$ & $222.50 \pm 2.12$ & $1.98 \pm 0.03$ \\
Cabinet dried & $745.50 \pm 6.36$ & $26.53 \pm 0.03$ & $254.50 \pm 2.12$ & $1.84 \pm 0.03$ \\
f value & $797.005^{*}$ & $10063.556^{*}$ & $1213.957^{*}$ & $107.995^{*}$ \\
\hline \multicolumn{7}{l}{ Values are expressed as Mean \pm SE; ${ }^{*}$ Significant at $5 \%$ level; Samples were taken in triplicate. }
\end{tabular}


Kaur, G. and Kaur, N. / J. Appl. \& Nat. Sci. 10 (4): 1149 -1155 (2018)

Table 4. Effect of processing on the amino acid content of fresh and dried leaves of bathua by different techniques (DM basis).

\begin{tabular}{llll}
\hline Treatment & Methionine $(\mathbf{m g} / \mathbf{1 0 0})$ & Tryptophan $(\mathbf{m g} / \mathbf{1 0 0 g})$ & Available Lysine $\mathbf{( m g / 1 0 0 g})$ \\
\hline Fresh leaves & $42.00 \pm 1.41$ & $25.00 \pm 2.83$ & $703.50 \pm 10.61$ \\
Dehydrated leaves & & & \\
Sun dried & $297.00 \pm 1.41$ & $154.00 \pm 4.24$ & $810.00 \pm 1.41$ \\
Solar dried & $271.50 \pm 2.12$ & $141.00 \pm 2.83$ & $826.50 \pm 4.95$ \\
Shade dried & $262.50 \pm 2.12$ & $73.50 \pm 2.12$ & $796.50 \pm 0.71$ \\
Cabinet dried & $341.50 \pm 3.54$ & $169.50 \pm 3.54$ & $853.50 \pm 4.95$ \\
f value & $426.745^{* *}$ & $332.930^{* *}$ & $93.524^{* *}$ \\
\hline
\end{tabular}

Values are expressed as Mean \pm SE; ${ }^{*}$ Significant at $5 \%$ level; Samples were taken in triplicate.

Table 5. Effect of processing on the in vitro of fresh and dried leaves of bathua by different techniques (DM basis).

\begin{tabular}{ll}
\hline Treatment & $\begin{array}{l}\text { In vitro protein digestibility } \\
\text { (\%) }\end{array}$ \\
\hline Fresh leaves & $10.51 \pm 0.40$ \\
Dehydrated leaves & \\
Sun dried & $25.20 \pm 0.14$ \\
Solar dried & $25.80 \pm 0.14$ \\
Shade dried & $26.25 \pm 0.21$ \\
Cabinet dried & $27.75 \pm 0.07$ \\
f value & $105.333^{*}$ \\
\hline
\end{tabular}

Values are expressed as Mean \pm SE, * Significant at $5 \%$ level, Samples were taken in triplicate.

sults are in agreement with the work of other researchers (Vishwakarma and Dubey, 2011) who reported $54.04 \mathrm{~g}$ of carbohydrates in fresh leaves. On the other hand, Pandey and Pathak (2009) reported $4.9 \mathrm{~g}$ carbohydrate content in fresh leaves whereas Singh et al. (2007) reported the carbohydrate content of leaves to be $5.36 \mathrm{~g} / 100 \mathrm{~g}$ and for dehydrated leaves it was $34.36 \mathrm{~g} / 100 \mathrm{~g}$. A negligible difference was found between the calculated value of energy of raw $(390.33 \mathrm{kcal})$ and processed samples i.e. sun $(319.48 \mathrm{kcal} / 100$ g), shade $(329.55 \mathrm{kcal})$, solar $(324.61 \mathrm{kcal})$ and cabinet $(309.55 \mathrm{kcal}) / 100 \mathrm{~g}$ dried leaves. Vishwakarma and Dubey(2011) reported energy value of leaves as $271.4 \mathrm{kcal}$ per $100 \mathrm{~g}$ of leaves.

Vitamin content: Vitamin C content (Table 2) of fresh leaves was estimated to be $37 \mathrm{mg} / 100 \mathrm{~g}$. On dehydration, the amount of ascorbic acid was decreased in comparison to fresh leaves. This value was quite similar to the value given by Raghuvanshi et al. (2009) reported the nutritional composition of uncommon foods and found that ascorbic acid ranged between 3.26 to 173.13 $\mathrm{mg} / 100 \mathrm{~g}$. The ascorbic acid ranged between 21 (cabinet dried) to 34 (shade dried) $\mathrm{mg} / 100 \mathrm{~g}$ in dehydrated leaves. Joshi and Mathur (2010) reported that fresh drumstick leaves had $220 \mathrm{mg} /$ $100 \mathrm{~g}$ of ascorbic acid. The leaf powder prepared by different methods of dehydration had ascorbic acid $92 \mathrm{mg} / 100 \mathrm{~g}$ (sun dried), $140 \mathrm{mg} / 100 \mathrm{~g}$ (shadow dried) and $56 \mathrm{mg} / 100 \mathrm{~g}$ (oven dried) leaf powder. The amount of ascorbic acid was maximum in shadow dried sample as the leaves were not exposed to direct heat and air in this technique.

The $\beta$-carotene contentof fresh leaves was evaluated as $1700 \mu \mathrm{g} / 100 \mathrm{~g}$. Dehydrated leaves were more concentrated source of $\beta$-carotene than fresh leaves. This value was comparable to the value mentioned by Singh et al. (2007) who reported $\beta$-carotene content of dehydrated leaves as $14826 \mu \mathrm{g} / 100 \mathrm{~g}$ which was 6-8 times greater than fresh values. The maximum retention of $\beta$ carotene was observed in cabinet drying technique i.e. $14323.50 \mu$ gfollowed by shade $(13990.00 \mu \mathrm{g})$, sun $(12892.50 \mu \mathrm{g})$ and solar drying technique (11604.50) /100g. Dutta et al. (2005) reported that blanching increases the beta carotene content perhaps because of greater chemical extractability and loss of moisture and soluble solids which further concentrate the sample. Inactivation of certain oxidative enzymes takes place and it results in the breakdown of some structures leading to a higher net bioavailability of betacarotene.

Mineral content: Fresh leaves showed 142.50 mg calcium (Table 3 ) which was found close to the value mentioned by Uusikuet al. (2011) and Kowsalya and Vidhya (2004) for calcium. Post processing enhanced calcium contentof leaves significantly $(p \leq 0.05)$. Dehydration of leavesleads to concentration of calcium by 4 to 5 folds. Maximum increment was observed by cabinet, followed by shade $(691.00 \mathrm{mg})$, sun $(654.50 \mathrm{mg})$ and solar $(549.00 \mathrm{mg}) / 100 \mathrm{~g}$ dried technique.

Fresh leaves have an iron content of 4.15 $\mathrm{mg} / 100 \mathrm{~g}$ where as the iron content (Table 3 ) of the leaf powder prepared by different methods of dehydration (Sun, Shade, solar and cabinet) was estimated to be $22.28 \mathrm{mg} / 100 \mathrm{~g}$ (Sun dried), 24.45 $\mathrm{mg} / 100 \mathrm{~g}$ (Shade dried), $21.67 \mathrm{mg} / 100 \mathrm{~g}$ (solar dried) and $26.53 \mathrm{mg} / 100 \mathrm{~g}$ (cabinet dried) which was 95 to $96 \%$ more than their fresh counter parts. Laxmi and Kohila (2007) reported the results similar to analysed values. The iron content of fresh Agathi was $3.9 \mathrm{mg} / 100 \mathrm{~g}$. On dehydration, the iron content raised to $22.7 \mathrm{mg} / 100 \mathrm{~g}$ (Sun dried), $25.3 \mathrm{mg} / 100 \mathrm{~g}$ (Shade dried) and 24.6 $\mathrm{mg} / 100 \mathrm{~g}$ (Cabinet dried). On the other side, Singh et al. (2007) reported $5.76 \mathrm{mg} / 100 \mathrm{~g}$ of iron in fresh leaves. 
Kaur, G. and Kaur, N. / J. Appl. \& Nat. Sci. 10 (4): 1149 -1155 (2018)

Table 6. Effect of processing on the anti nutritional factors of fresh and dried leaves of bathua by different techniques (DM basis).

\begin{tabular}{llll}
\hline Treatment & Phytates & Total phenols & Oxalates \\
\hline Fresh leaves & $250.00 \pm 2.83$ & $214.00 \pm 4.24$ & $162.50 \pm 2.12$ \\
Dehydrated leaves & $143.49 \pm 0.07$ & $179.50 \pm 2.12$ & $115.35 \pm 0.21$ \\
Sun dried & $138.27 \pm 2.05$ & $165.75 \pm 1.77$ & $126.20 \pm 0.28$ \\
Solar dried & $178.73 \pm 1.06$ & $138.27 \pm 1.41$ & $131.50 \pm 0.42$ \\
Shade dried & $116.15 \pm 1.48$ & $153.40 \pm 0.57$ & $85.30 \pm 0.42$ \\
Cabinet dried & $832.6^{*}$ & $2583.755^{*}$ & $72506.787^{*}$ \\
f value &
\end{tabular}

Values are expressed as Mean \pm SE, * Significant at $5 \%$ level, Samples were taken in triplicate.

Magnesium content of fresh leaves was found to be53.50 mg per $100 \mathrm{~g}$ which coincides with the value $(54.7 \mathrm{mg}$ to $146 \mathrm{mg} / 100 \mathrm{~g}$ ) reported by Schonfeld and Pretorius (2011) while contradicts with the values $(3.14$ and $160.60 \mathrm{mg} / 100 \mathrm{~g}) \mathrm{re}-$ ported by Zhang et al.(2011) and Hassan et al. (2011). Maximum and significant ( $p \leq 0.05$ ) result was estimated after cabinet drying $(253.50 \mathrm{mg} / 100$ g) where as minimum and significant result was recorded after solar drying $(157.00 \mathrm{mg} / 100 \mathrm{~g})$.

Processing affected the zinc value of bathualeaves(Table 3). It was found $0.50 \mathrm{mg} / 100 \mathrm{~g}$ in fresh leaves while itincreased maximum after shade $(1.98 \mathrm{mg})$, followed by cabinet $(1.84 \mathrm{mg})$, sun $(1.61 \mathrm{mg}$ ) and solar (1.49 mg) /100g drying. Zhang et al. (2011) reported that bathua leaves contained $3.14 \mathrm{mg} / 100 \mathrm{~g}$ of zinc. The results are in line with Schonfeld and Pretorius (2011) who reported that dark green leafy vegetables of South Africa contained $0.5 \mathrm{mg}$ to $1.0 \mathrm{mg} / 100 \mathrm{~g}$ of zinc.

Amino acid analysis: Fresh leaves had $42 \mathrm{mg}$ methionine per $100 \mathrm{~g}$ of protein which helps to maintain proper nitrogen balance of body (Table $4)$. It was increased with the application of processing. The maximum and significant value (341.50 mg/100g) was observed on cabinet drying, followed by sun drying with significant difference as compared to fresh leaves. Sood (2007) reported $49 \mathrm{mg} / 100 \mathrm{gof}$ protein in bathua leaves which is comparable with the present result. The analysed value coincides with the value (50mg/100g) reported by Gopalan et al. (2004) but contradicts the value $(1.17 \mathrm{mg} / 100 \mathrm{~g})$ reported by Aremu et al. (2011).

Tryptophan (Table 4) which is required for vitamin synthesis such as niacin and is used to make important brain chemicals was found to be 25 $\mathrm{mg} / 100 \mathrm{~g}$ of protein in fresh leaves. On dehydration, the tryptophan content was increased. Among all the dehydration techniques, maximum retention of tryptophan was seen in cabinet drying technique i.e. $169.50 \pm 3.54 \mathrm{mg} / 100 \mathrm{~g}$. Gopalan et al. (2004) observedtyptophan content of fresh bathualeavesas $20 \mathrm{mg}$ per $100 \mathrm{~g}$ protein. Sood (2007) reported tryptophan content in Chenopodium album leaves as $39 \mathrm{mg} / 100 \mathrm{~g}$.

Lysine content in fresh bathua leaves was found to be $703.50 \mathrm{mg} / 100 \mathrm{~g}$. On dehydration, the lysine content was increased however, maximum increment was observed in cabinet drying technique $(853.50 \mathrm{mg} / 100 \mathrm{~g})$ and minimum increment was observed in shade drying technique $(796.50 \mathrm{mg} / 100 \mathrm{~g})$. The lysine content of the study agrees with the results of lysine of fresh bathua leaves reported by Gopalan et al. (2004).

It may be concluded from the data that methionine, tryptophan and lysine content was observed maximum in cabinet drying technique followed by sun drying technique.

In vitro protein digestibility: In vitro protein digestibility of fresh bathua leaves was analyzed as 10.51 percent (Table 5). Processing improved protein digestibility of leaves. In vitro protein digestibility content of the dehydrated bathua leaves prepared by different methods of dehydration was 25.20 percent (sun dried), 26.25 percent (shade dried), 27.75 percent (cabinet dried) and 25.80 percent (solar dried). The results obtained were similar to values (9.78 to $14.48 \%$ ) reported by Raghuvanshi et al. (2009) in underutilized foods.

Anti nutritional factors (Phytates, oxalates and total phenols: Antinutritional components are known to reduce the bioavailability of nutrients in the body.

Phytates (Table 6) can bind to certain minerals such as calcium, iron, zinc and magnesium and decrease their absorption (Nduagu et al. 2008). Phytate content of fresh leaves was evaluated as $250 \mathrm{mg}$ per $100 \mathrm{~g}$ which is similar to the value (238.3 to 268.33) reported byAli (2015). The value was found to be decreased by processing methods applied on it. The level of phytate was reduced significantly ( $p \leq 0.05$ ) by cabinet followed by solar, sun and shade drying technique. Ilelaboyeet al.(2013) studied the effect of cooking methods on mineral and anti nutrient content of green leafy vegetables. The phytate content of fresh leaves was $210.54 \mathrm{mg} / 100 \mathrm{~g}$ (Taliumtriangulae), $155 \mathrm{mg} / 100 \mathrm{~g}$ (Amaranthus hydrides) which was reduced to $106.20 \mathrm{mg} / 100 \mathrm{~g}$ (Taliumtriangulae), $78.31 \mathrm{mg} / 100 \mathrm{~g}$ (Amaranthus hydrides) after processing.

The oxalates content of fresh bathua leaves was estimated as $162.50 \mathrm{mg} / 100 \mathrm{~g}$. On dehydration, the oxalates content of bathua was reduced, minimum and maximum amount was observed in cabinet 
$(85.30 \mathrm{mg} / 100 \mathrm{~g})$ and shade drying technique $(131.50 \mathrm{mg} / 100 \mathrm{~g})$ respectively. Ilelaboyeet al. (2013) analysed the oxalate content of fresh leaves i.e. Taliumtriangulae (28.93 mg/100g), Amaranthus hydrides $(47.35 \mathrm{mg} / 100 \mathrm{~g})$. On processing it was reduced to $15.84 \mathrm{mg} / 100 \mathrm{~g}$ (Taliumtriangulae), $32.55 \mathrm{mg} / 100 \mathrm{~g}$ (Amaranthus hydrides). On the other hand, Paul et al. (2012) revealed that oxalic content of fresh spinach and bathua leaves were $88.8 \mathrm{mg} / 100 \mathrm{~g}$ and 174.5 $\mathrm{mg} / 100 \mathrm{~g}$ respectively which were reduced to 48.4 $\mathrm{mg} / 100 \mathrm{~g}$ (spinach) and $58.6 \mathrm{mg} / 100 \mathrm{~g}$ (bathua leaves) after processing.

The dehydrated bathua leaves contain significantly $(p \leq 0.05)$ lower amount of total phenols than that of fresh bathua leaves. However, minimum amount of total phenols was observed in shade (138.27 mg/100g) drying technique.

\section{Conclusion}

Bathua (Chenopodium album) leaves are loaded with appreciable amounts of amino acids, calcium and iron which are beneficial for adequate growth and development. The results of the study revealed that processing has improved the nutrient content and reduced the anti nutritional factors of bathua (Chenopodium album) leaves significantly. Improvement in proximate composition, mineral content and In vitro protein digestibility was observed with processing. Maximum retention of nutrients was found with cabinet drying technique as compared to others such as sun, shade and solar drying techniques. Being economical and tremendously rich in nutrients, dehydrated bathua (Chenopodium album) can be an alternative to overcome micro-nutrient deficiencies among the vulnerable sections of the society.

\section{REFERENCES}

1. Abeza R H, Black J T and Fisher E J (1968) Oxalate determination. Analytical problems encountered with certain plant species. J Assoc Official Anal Chemists 51: 853.

2. Ahmad, M., Mohiuddin, O.A., Mehjabeen, Jahan, N., Anwar, M., Habib, S., Alam, S.M.,andBaig, I.A. (2012). Evaluation of spasmolytic and analgesic activity of ethanolic extract of Chenopodium album Linn and its fractions. Journal of Medicine Plant andResearch, 6, 4691-4697.

3. Akeson, W.E., and Stachmann, M.A. (1964).A pepsin - pancreatin digest index of protein quality evaluation. Journal of Nutrition, 83, 257.

4. Ali, E. (2015). The chemical constituents and pharmacological effects of Chenopodium album. International Journal of Pharmacy, 5, 10-17.

5. AOAC (2000). Official methods of analysis, 13th edition, Association of Official Analytical Chemists. Washington DC

6. AOVC (1996) Methods of vitamin assay. Association of Vitamin Chemists Inc. (Ed.) Interscience publishers. Pp 306-12.

7. Aremu, M.O., Nweze, C.C., and Alade1, P. (2011).
Evaluation of protein and amino acid composition of selected spices grown in the middle belt region of Nigeria. Pakistan Journal of. Nutrition, 10, 991-995.

8. Concon, J.M. (1975). Rapid and simple method for determination of tryptophan in cereal grains. Analytical Biochemistry, 67, 206.

9. Dutta, D., Raychaudhuri, U., Chakraborty, R. (2005). Retention of $\beta$-carotene in frozen carrots under varying conditions of temperature and time of storage. African Journal of Biotechnology, 4, 102-103.

10.Gopalan, C., Sastri, B.V.R., andBlasubramanian, S.C. (2004).Nutritive value of Indian foods. National Institute of Nutrition, Indian Council of Medical Research, Hyderabad, India.

11.Gupta, S, Gowri, B.S., Lakshmi, J andPrakash (2011). Retention of green leafy vegetables on dehydration. Journal of Food Science and Technology,50, 918-925.

12.Hassan, L.G., Hassan, S.W., Hashim, T, Umar, K.J., andSani, N.A. (2011). Determination of nutritive values of garden cress (Lepidium sativum) leaves. Bayero Journal of Applied Sciences, 4, 18-23.

13. Haug, W.,andLantzsch, H.T. (1983). Sensitive method for rigid determination of phytate in cereal and cereal products. Journal of ScienceofFood and Agriculture, 34, 14-23.

14.Hernandez, B.J.E., and Leon, J. (1994).Neglected crops: 1492 from a different perspective-FAO plant production and protection (pp. 307-310). Rome, Italy: Foodand Agriculture Organization of United Nations.

15.Horn, J.M., Jones, D.B., andBlum, A, E. (1946). Colorimetric determination of methionine in proteins and foods. Journal of Biological Chemistry, 166, 313-320.

16.llelaboye, AmooandPikuda(2013). Effect of cooking methods on mineral and anti nutrient composition of some green leafy vegetables. Applied of Scienceand Research, 5, 254-260.

17.Joshi, P.,andMathur, B. (2010).Preparation of value added products from the leaf powders of dehydrated less utilized green leafy vegetables. Journal of Horticulture andForestry, 2, 223-238.

18.Kowsalya. S.,andVidhya, M. R. (2004). Nutritive value of selected dehydrated green leafy vegetables. Indian Journal of Nutrition andDietetics, 42, 279-286.

19.Nduagu, C., Ekefan, E. J.,andNwankiti, A.O. (2008). Effect of some crude plant extracts on growth of colletotrichumcapsici (Synd) Butler and Bisby, causal agent of pepper anthracnose. Journal of Applied Biosciences, 6(2), 184-190.

20.Laxmi, U.K., andKohila, B. (2007). Development and evaluation of vegetable based antioxidant mixes. Indian Journal of Nutrition and Dietetics, 44, 471475.

21.Pandey, M.,andPathak, A. (2009). An overview of Chenopodium album (Bathua sag) chemistry and pharmacological profile. Journal of Pharmacy and Chemistry, 3, 79-81.

22.Pandey, S., andGupta, R. (2014). Screening of nutritional, phytochemical, antioxidant, antibacterial activity of Chenopodium album. Journal of Pharmacognosy and Phytochemistry, 3, 1-9.

23.Paul, V., Verma, S., andSushmaand, P.A. (2012). Effect of cooking and processing methods on oxalate content of green leafy vegetables and pulses. Asian Journal of Foodand Agro- Industry, 5, 311-314.

24.Rangana, S. (1995). Handbook of analysis and quality control for fruits and vegetable products. Tata 
Kaur, G. and Kaur, N. / J. Appl. \& Nat. Sci. 10 (4): 1149 -1155 (2018)

Mcgraw-Hill Publishing Company Limited, New Delhi. 25.Raghuvanshi, R.S., Singh, R., andSingh R. (2009).Nutritional composition of uncommon foods and their role in meeting micronutrient needs. International Journal of Food Sciences and Nutrition, 52, 331-335.

26.Schonfeld and Pretorius (2011). The nutrient content of five traditional South African dark green leafy vegetables. Journal of Food Composition andAnalysis, 24, 1141-1146.

27.Sikarwar, I., Wanjari, M., Baghel, S.S. and Vashishtha, P. (2013).A review on phytopharmacological studies on Chenopodium album Linn.Indo American Journal of Pharmaceutical Research, 3, 3089-3098.

28.Singh, L., Yadav, N., Kumar, A.R., Gupta, A.K., Chacko, J., Parvin, K., andTripathi, U. (2007). Preparation of value added products from dehydrated bathualeaves (Chenopodium album Linn.). Natural Product Radiance, 6, 6-10.

29.Sood, P. (2007).Physico-chemical, nutritional, biological quality evaluation and value addition of chenopo- dium (bathua) cultivars. M.Sc. thesis, Chaudhary Sarwan Kumar Himachal Pradesh Krishi Vishvavidyalaya, Palampur, HP, India.

30.Swaminathan, M. (1974) Essentials of foods and nutrition (p. 27). Madras, India: Ganesh and company.

31.Uusiku, N.P., Oelofse, A., Duodu, K.G., Bester, M.J. and Faber, M. (2010). Nutritional value of leafy vegetables of sub-Saharan Africa and their potential contribution to human health. Journal of Food Composition and Analysis, 6, 499-509.

32.Vishwakarma andDubey (2011).Nutritional analysis of indigenous wild edible herbs used in eastern Chhattisgarh. Journal of Food andAgriculture, 23, 554 -60 .

33.Zhang, M., Navam, S., Horax, R., Kanna, A., Praisoody, A., Muhundan, A., and Mallangi, C. (2011).Phtochemicals, antioxidants and antimicrobial activity of Hibiscus sabdariffa, Centellaasiaticam Moringa oleifera and Murrayakoenigii leaves. Journal of Medicinal Plant Research, 5, 6672-80. 